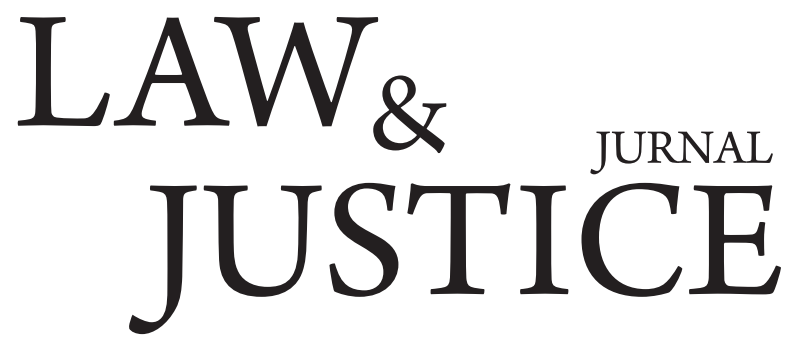

Volume 4, Nomor 1, April 2019

\title{
Menggali Kembali Peran Pancasila sebagai Ideologi Bangsa dan Dasar Negara dalam Pembangunan Hukum Nasional di Era Global
}

\author{
Agna Suaila,SH.M.Hum \\ Email: agnachairi@gmail.com \\ Johny Krisnan SH.M.Hum \\ Fakultas Hukum \\ Universitas Muhammadiyah Magelang \\ Email: johnykrisnan@gmail.com
}

\begin{abstract}
Abstrak
Era Global atau yang sekarang turunannya dikenal dengan era Industri 4.0 ternyata membawa dampak luar biasa bagi tatanan kehidupan berpolitik, berbangsa dan bernegara. Dampak positifnya tentu tidak perlu dibahas, tetapi dampak negatifnya sangat membawa konsekuensi perubahan prilaku bangsa Indonesia yang berdasarkan Pancasila. lahirnya gerakan reformasi pada tahun 1988 tampaknya menjadi titik klimaks adanya perubahan sistem bernegara itu, yang suka atau tidak suka juga sangat berpengaruh besar bagi kehidupan masyarakat di dalam mengamalkan dan menafsirkan Pancasila yang cenderung makin berbahu liberal, bila tidak dikendalikan. Usaha untuk memurnikan nilai Pancasila agar searah dengan akar budaya bangsa kita harus dilakukan, dan ternyata tidaklah mudah, dan tidak cukup hanya menggunakan kacamata hukum sebagai alat. Pendekatan Holistik yang mencakup pendekatan Spiritual Quotion adalah solusinya.
\end{abstract}

Kata kunci: Globalisasi-akselerasi nilai Pancasila-pendekatan spiritual.

\section{Pendahuluan}

Pancasila yang tercantum di dalam Pembukaan UUD 1945 berkualifikasi sebagai dasar negara, serta mengandung filosofi politik, karena para founding father ketika itu meletakkan Pancasila dalam suatu obyek khusus, yaitu konteks kehidupan bernegara. Selain paradigma kehidupan bernegara, para pendiri negara juga menempatkan Pancasila sebagai cita hukum, yang berdimensi luas, baik tata hukum yang dirumuskan dalam teks UUD 1945 maupun di luar itu, baik yang tertulis maupun tidak tertulis. Ini mengandung maksud bahwa ideologi ${ }^{1}$ Pancasila seharusnya menjadi kekuatan yang mengikat secara moral bagi seluruh subyek hukum di bumi Indonesia. Artinya, tiap subyek kehidupan negara wajib

1 Dalam Web berbahasa Inggris, ideologi antara lain diartikan sebagai : (a) a complex concept, in its basic form it is aset of idea or beliefs whic are held to be acceptable by the creator of media text. (2)the knowledge of beliefs developed by human societies as part as their cultural adaption (3) means to favor one point of view above all others and to adhere to this point view. The ideologue sees the world from a single poin of view, can this "explain" it and attempt to "change" it. 
mengamalkan Pancasila dan menjalankan semua fungsi parsialnya dalam mewujudkan cita-cita bangsa, yaitu "negara Indonesia yang merdeka. Bersatu, berdaulat adil dan makmur". Tatanan kehidupan yang digambarkan dalam Pembukaan di atas memang masih abstrak sehingga acapkali berakibat multi tafsir. Sifat dan hakikat yang demikian sering menjadi sebuah kekuatan, sekaligus kelemahan dari Pancasila itu sendiri yang di dalam sejarahnya banyak mengalami ujian-ujian dalam bentuk penyelewengan di dalam pelaksanaannya ${ }^{2}$.

Pengaruh Globalisasi yang melanda bangsa Indonesia tentunya berdampak pada adanya "perubahan" paradigma dalam memahami pengamalan Pancasila. Gerakan Reformasi yang begulir pada awal tahun 1997 telah dipandang sedemikian rupa sebagai titik tolak untuk mengevaluasi ulang perjalanan orde baru yang konon dalam beberapa hal juga telah melanggar nilai-nilai Pancasila. Tudingan atas terjadinya Korupsi, kolusi dan Nepotisme (KKN) pada masa pemerintahan Suharto waktu itu dijadikan dasar bahwa apa yang dilakukan presiden kedua Republik Indonesia ini juga telah melanggar Pancasila ${ }^{3}$ .Dengan globalisasi berarti bangsa Indonesia telah memasuki periode baru dalam sejarah manusia. Suatu babakan yang membawa visi, cara berfikir

2 Di dalam buku Bahan Penataran Pedoman Penghayatan dan Pengamalan Pancasila secara jelas dinyatakan sebagai berikut “ Jalan lurus pelaksanaan Pancasila juga mendapat rintangan rintangan dengan adanya pemutarbalikan Pancasila dan dijadikannya Pancasila sebagai tameng untuk menyusupkan paham dan edeologi yang justru bertentangan dengan nilainilai Pancasila. Masa ini di tandai antara lin dengan memberi arti kepada Pancasila sebagai "nasakom", ditampilkannya pengertian "sosialisme Indonesia" sebagai "marxisme" yang diterapkan di Indonesia dan banyak penyimpanan-penyimpangan lainnya yang bersifat sangat mendasar. Masa pemutarbalikan ini bertambah kesimpangsiurannya karena masing-masing kekuatan politik, golongan atau kelompok di dalam waktu itu memberi arti sempit kepada Pancasila untuk keuntungan dan kepentingannya sendiri" Periksa buku Bahan Penataran P4. BP7 Pusat, 1990, hal 11.

3 Isu HAM yang bergulir waktu itu benar-benar menjadi senjata ampuh untuk menyerang Pemerintahan Soharto waktu itu, sehingga Timor-Timur yang semula menjadi bagian NKRI harus lepas. Begitu pula kasus Tanjung Priuk yang semula telah dilupakan orang tiba-tiba kembali muncul sebagai bumerang yang mengancam kekuasaan Pemerintahan Soeharto, termasuk tentunya isu penguasaan jaringan ekonomi keluarga Cendana yang dipandang memanfaatkan kekuasaan untuk kepentingan pribadi kroni-kroni. dan cara kerja yang berbeda dibanding dengan era sebelumnya ${ }^{4}$. Teknologi baru media elektronika dan komunikasi benar-benar telah menerobos batas-batas wilayah negara, sehingga kejadian dan peristiwa di bumi manapun dan kapanpun tidak dapat disembunyikan dari pengamatan manusia. Tampaknya ruang dan waktu tidak lagi merupakan kendala di zaman sekarang, sehingga kompresi waktu membuat dunia seolah-olah ada pada genggaman tangan manusia. Kemajuan teknologi juga semakin mengubah tatanan era Industri yang saat ini makin mengarah pada munculnya era baru yang dikenal dengan Industri 4.0

Karakteristik model dari Industri 4.0 adalah kombinasi dari beberapa perkembangan teknologi terbaru seperti sistem siber fisik, teknologi informasi dan komunikasi, jaringan komunikasi, big data dan cloud computing, pemodelan, virtualisasi, simulasi serta peralatan yang dikembangkan untuk kemudahan interaksi manusia dengan komputer. Konsep industri 4.0 menjanjikan banyak peluang perubahan positif terhadap industri manufaktur saat ini, diantaranya adalah kemampuan kustomisasi massal, fleksibilitas produksi, meningkatkan kecepatan produksi, kualitas produk yang lebih tinggi, menurunkan rata-rata kegagalan, mengoptimalkan efisiensi, pengambilan keputusan berdasarkan data, hubungan kedekatan dengan pelanggan yang lebih baik, metode baru dalam penciptaan nilai (value) serta memperbaiki kehidupan kerja ${ }^{5}$

Era globalisasi juga menampakkan diri sebagai era dominasi negara-negara industri maju atas negara-negara berkembang. Runtuhnya blok Uni Soviet bersama negara-negara di blok timur-Tengah pada tahun 1989 menjadi stimulus bagi negara-negara barat untuk menguasai secara ekonomik daerah green area ini untuk menjadi bagian hegemoni mereka dengan tujuan terjaminnya persediaan sumber daya alam bagi kepentingan industrinya ${ }^{6}$. Berkaitan dengan proses

4 Menurut Roland Robertson, Globalisasi adalah “ a concept refers both to the compression of the world and the intensification of consiousness of the world as a whole" (Roland Robertson, Globalization, SAGE Publications Ltd, London. 1993, hal 8.

5 Rahman Fauzan, KARAKTERISTIK MODEL DAN ANALISA PELUANG-TANTANGAN INDUSTRI. 4.0. http://ejournal.polihasnur.ac.id/index.php/pha/article/ view/271- edisi april 2018,

6 Jerry Mander \& Edward Coldsmith, The Case Again Global Economy and For A return Toward the Local, Siera Club Books, San Fransisco, 1996, hal 21 
Globalisasi ini maka terdapat banyak perusahaan multi nasional yang berkembang mengusai dunia, khususnya melalui program SAPS ( Structural Adjustment Programs), IMF ( International Monetary Found) atau bahkan Bank Dunia yang dalam praktik menekan negara-negara berkembang untuk membuka kedaulatan nasionalnya untuk kepentingan ekonom pasar bebas.

Perjanjian perdagangan yang dinegoisasi melalui GATT makin menegaskan kecenderungan terjadinya arah pasar bebas ini di antara dua kelompok negara selatan dan utara yang semula memiliki karakter sistem perekonomian yang berbeda. Namun demikian gejala ke arah terbentuknya pasar bebas ini sesungguhna telah nampak secara eksplisit maupun implisit oleh masyarakat Internasional, misalnya dengan terbentuknya organisasi ekonomi regional yang beranggotakan sejumlah negara yang berkepentingan dalam bidang ekonomi ${ }^{7}$. Pengaruh gobalisasi ini tentunya tidak hanya menjalar di bidang politik dan ekonomi seperti terungkap di atas, tetapi juga sama halnya terjadi dibidang tatanan hukum yang dibuat bangsa Indonesia. Dengan dilakukannya amandemen atas UndangUndang Dasar 1945 sebanyak 4(empat) kali di era reformasi, maka sesungguhnya telah banyak yang berubah di dalam sistem ketatanegaraan yang berlaku sekarang. Jika dulu MPR memiliki kekuasaan yang tertinggi atas negara, sekarang kewenangan itu telah dikurangi, karena tidak lagi berhak memilih kepala negara sendiri, tetapi untuk urusan ini dikembalikan langsung kepada rakyat. Jika lembaga ini dulu berwenang menetapkan GBHN, sekarang kewenangan itu sudah dihapus 8. Tidak adanya Garis Besar Haluan Negara ini -dalam praktik- ternyata menimbulkan masalah karena pemerintah kemudian tidak memiliki

7 Misalnya ASEAN, MEE, APEC dan ASEM

8 Pasal layat (2) UUD 1945 sebelum dubah berbunyi : "kedaulatan adalah di tangan rakyat, dan dilakukan sepenuhnya leh Majlis Permusyawaratan Rakyat". Pasal ini diamandemen menjadi "Kedaulatan ada di tangan Rakyat dan dilaksanakan menurut Undang-Undang Dasar". Selanjutnya Pasal 3 lama yang berbunyi Majelis Permusyawaratan Rakyat menetapkan UndangUndang Dasar dan Garis Bear Haluan Negara" telah diamandemen menjadi (1) Majelia Permusayawaratan Rakyat berwenang mengubah dan menetapkan UndangUndang Dasar, (2) Majelis Permuayawaratan Rakyat melantik Presiden/atau Wakil Presiden (3) Majelis Permusyawaratan Rakyat hanya dapat memberhentikan Presiden dan/atau Wakil Presiden dalam masa jabatannya menurut Undang-Undang Dasar. mandat yang jelas di dalam melaksanakan roda pemerintahannya. Baru kemudian lahir Undang-Undang Nomor 24 Tahun 2007 Tentang arah Kebijakan Pembangunan Jangka Panjang Nasional 2005-2025. Oleh karena itu wajar bila selama terjadinya kekosongan hukum, kondisi pembangunan bangsa yang dimulai sejak pemerintahan Presiden yang dipilih lansung oleh rakyat pada tahun 2005 menjadi kurang memiliki arah yang jelas.

Inilah beberapa catatan yang perlu diketengahkan untuk dikaji kembali, mengingat ada sinyalemen bahwa apa yang telah dilakukan bangsa selama melaksanakan program reformasi ternyata membawa dampak negatif seperti timbulnya kesenjangan sosial dan ekonomi, kecenderungan berlebihan dalam memaknai nilai demokrasi, konflik horizontal dan lain-lain yang semua itu bermuara pada indikasi lemahnya bangsa ini dalam menghayati dan mengamalkan nilai-nilai Pancasila. Atas dasar pertimbangan ini, penulis memilih judul penelitian, "Menggali Kembali Peran Pancasila Sebagai Ideologi Bangsa Dan Dasar Negara Dalam Pembangunan Hukum Nasional Di Era Globalisasi”.

\section{Permasalahan}

Berdasarkan latar belakang di atas, dapat disimpulkan beberapa rumusan masalah yang akan dikaji sebagai berikut:

1. Bagaimana reformasi sebagai sebuah ealita gerakan bangsa dalam membangun kembali tatanan kehidupan berbangsa dan bernegara?

2. Bagaimana globalisasi dan implikasinya terhadap pengamalan Pancasila?

3. Bagaimana langkah-langkah hukum dalam meletakkan kembali jiwa Pancasila sebagai arah pembangunan bangsa?

\section{Pembahasan Masalah}

Reformasi sebagai Sebuah Realita Gerakan Bangsa untuk Membangun Kembali Tatanan Kehidupan Berbangsa dan Bernegara.

Pada tanggal 21 Mei 1998 Presiden Soeharto menyatakan berhenti dari jabatan presiden, setelah terjadi unjuk rasa besar-besaran yang dimotori mahasiswa, pemuda dan berbagai komponen bangsa lainnya di Jakarta maupun di daerah-daerah. Sejarah berhentinya presiden 
Soeharto di tengah krisis ekonomi dan moneter yang sangat memberatkan kehidupan masyarakat Indonesia menjadi awal dimulainya era reformasi di tanah air9. Era reformasi ini memberikan harapan besar bagi terjadinya perubahan menuju penyelenggaraan negara yang lebih demokratis, transparan dan memiliki akuntabilitas tinggi serta terwujudnya good goverenance dan adanya kebebasan berpendapat. Semuanya diharapkan makin mendekatkan bangsa ini pada pencapaian tujuan nasional sebagaimana terdapat pada Pembukaan Undang-Unang Dasar Republik Indonesia 1945. Gerakan reformasi diharapkan mampu mendorong perubahan mental bangsa Indonesia, baik pemimpin maupun rakyatnya sehingga mampu menjadi bangsa yang menganut dan menjunjung tinggi nilai-nilai kebenaran, keadilan, tanggungjawab, persamaan serta persaudaraan.

Pada awal reformasi, diketahui terdapat tuntutan masyarakat, termasuk mahasiswa dan pemuda yang menggelinding ibarat bola salju, antara lain : 1. Amandemen Undang-Undang Dasar 1945; 2. Penghapusan doktrin dwifungsi ABRI; 3. Penegakan supremasi hukum, penghormatan Hak Asasi Manusia (HAM) serta pemberantasan Korupsi, Kolusi dan Nepotisme $(\mathrm{KKN})$; 4.Desentralisasi dan hubungan yang adil antara pusat dan daerah (otonomi daerah); 5. Mewujudkan kebebasan pers; 6. Mewujudkan kahidupan demokrasi. Tuntutan untuk melakukan perubahan di atas kemudian dilaksanakan dengan penyelenggaraan pemilihan umum dengan hasil terjadinya amandemen Undang-Undang Dasar 1945 yang merupakan terobosan luar biasa dan mendasar, karena kebijakan politik pada era sebelumnya samasekali tidak menghendaki terjadinya upaya untuk melakukan perubahan ${ }^{10}$. Pada Tahun 1998 Ketetapan MPR Nomor IV/ MPR/1983 ini kemudian dicabut karena dipandang bertentangan dengan bunyi Pasal 37 Undang Undang Dasar $1945^{11}$.

9 Panduan Pemasyarakatan Undang-Undang Dasar Negara Republik Indonesia Tahun 1945 (PPUUD 1945), sesuai dengan Urutan Bab, Pasal, dan Ayat, Sekretaris Jenderal MPR RI, 2015, hal 3.

10 lihat Ketetapan MPR Nomor IV/MPR/1983 tentang referedum, yang berisi kehendak rakyat untuk tidak melakukan perubahan Undang-Undang Dasar 1945, karena diperlukan syarat yang sangat berat dan ketat jika bangsa ingin elakukannya, yaitu harus minta persetujuan langsung dari rakyat

11 PPUUD 1945, Ibid, halaman 10. yaitu dengan Ketetapan
Ketetapan MPR penting lainnya yang menyangkut tuntutan reformasi adalah Ketatapan MPR No XIII/MPR/1998 Tentang Pembatatasan masa jabatan Presiden Republik Indonesia. Pasal 1 Ketetapan MPR nomor XIII/MPR/1998 ini berbunyi "Presiden dan Wakil Presiden Republik Indonesia memegang jabatan selama masa lima tahun, dan sesudahnya dapat dipilih kembali dalam jabatan yang sama, untuk hanya satu kali masa jabatan" Ketentuan ini secara subtantial sebenarnya telah mengubah Pasal 7 UndangUndang Dasar 1945 yang berbunyi "Presiden dan wakil Presiden memegang jabatannya selama masa lima tahun, dan sesudahnya dapat dipilih kembali". Untuk memenuhi tuntutan masyarakat kaitannya dengan upaya penegakan HAM, MPR juga telah mengeluarkam Ketetatapan MPR Nomor XVII/MPR/1998 Tentang Hak Asassi Manusia. Terbitnya Ketetapan MPR ini juga dapat dipandang sebagai terobosan baru dalam rangka lebih menyempurnakan ketentuan mengenai HAM yang terdapat pada Pasal 27, 28 dan 29 ayat (2) ${ }^{12}$.

Untuk tuntutan penghapusan Dwifungsi ABRI, sebenarnya juga telah dilakukan begitu tegas, yaitu dengan dikeluarkannya Tap MPR No VI/MPR/2000 Tentang pemisahan Tentara Nasional Indonesia dan Kepolisian Negara Republik Indonesia dan Ketetapan MPR Nomor VII/MPR/2000 Tentang Peran Tentara Nasional Indonesia dan Kepolisian Negara republik Indonesia. Bahkan persoalan TNI /POLRI ini juga sudah diakomodir di dalam Perubahan kedua Undang-Undang Dasar $1945^{13}$. Ketiga produk MPR ini sesungguhnya telah merumuskan kembali eksistensi kelembagaan TNI dan POLRI, fungsinya, yurisdiksin perannya, maupun hubungan di antara keduanya, dan antara keduanya dengan masyarakat politik yang lebih luas ${ }^{14}$.

MPR Nomor VIII/MPR/1998 Tentang Pencabutan Tap MPR Nomor IV/MPR/1983 Tentang Referendum.

12 Tap MPR Nomor XVII/MPR/1998 disempurnakan lagi dengan dilakukannya penambahan Pasal 28, mulai 28 A s/d 28J yang isinya hampir sama dengan butirr-butir yang terdapat dalam Declaration of Human Right.

13 Periksa Pasal 30 Ayat (1) s/d Ayat (5) UUD 1945 hasil Amandemen.

14 Ringkasan eksekutif, Implikasi Reposisi TNI-POLRI di bidang Hukum, anonim, nontahun, hal 2. Ringkasan eksekutif ini merupakan abstraksi sebuah buku dengan judul yang sama, merupakan kumpulan tulisan beberapa pennulis yaitu Muhammad Fajrul Falah, Joko Setiono, marcus priyo Gunarto, Sigit Riyanto, Enny Nurbaningsih, Aminoto, Supriyadi, Eddy OS Hiarey dan Haribertus Jaka Triyana. Diterbitkan Univ Gajah 
Yang jelas guna memenuhi tuntutan aspirasi rakyat kala itu, Undang-Undang Dasar 1945 kemudian diamandemen sebanyak empat kali, tetapi bangunan Undang-Undang Dasar yang diubah dipandang tidak terpisahkan dengan naskah aslinya. Inilah yang dikenal dengan cara Adendum $^{15}$. Dengan telah dilakukannya perubahan Undang-Undang Dasar 1945 seperti naskah yang ada sekarang ini, maka sesungguhnya tuntutan reformasi sebagaimana yang teridentifikasi dalam 6 butir tuntutan, semuanya telah diakomodir dalam Undang-Undang Dasar 1945, sehingga tinggal seberapa jauh Undang-Undang di bawahnya mengatur lebih lanjut tuntutan rakyat itu di dalam pelaksanaannya.

Berbicara mengenai pelaksanaan reformasi hukum, sebenarnya telah banyak kemajuan yang dicapai dan dinikmati hasilnya. Hadirnya UndangUndang Nomor 22 Tahun 1999 Tentang PokokPokok Pemerintahan Daerah sebenarnya menjadi tonggak sejarah bagi terwujudnya otonomi daerah yang sesungguhnya ${ }^{16}$. Tetapi tampaknya ada pihak-pihak yang memandang bahwa hadirnya Undang-Undang itu ternyata berimplikasi pada munculnya uvoria kebebasan dan otorisasi kewenangan di daerah yang dipandang berlebihan bahkan cenderung menyimpang, sehingga jika hal ini dibiarkan dikhawatirkan akan muncul istilah "raja-raja kecil" di daerah yang sulit dikendalikan dan dapat mengancam keutuhan Negara Kesatuan Republik Indonesia (NKRI). Bahkan dalam praktiknya menghasilkan pemerintahan yang korup termasuk yang dilakukan oleh para wakil rakyat ${ }^{17}$.

Mada, 2001.

15 Artinya perubahan Undang-Undang Dasar 1945 itu dilakukan dengan tetap mempertahankan naskah aslinya sebagaimana terdapat dalam Lembaran Negara Nomor 75 tahun 1959 hasil dekrit Presiden 5 Juli 1959dan naskah Perubahan-perubahan UndangUndang Dasar 1945 diletakkan melekat pada naskah asli (ibid, halaman 14)

16 Menurut Ryaas Rasyid, hal-hal baru dalam Undangundang Nomor 22 Tahun 1999misalnya soal pemilihan kepala Daerah oleh DPRD, pembuatan peraturan juga tidak perlu disahkan oleh pusat, sumber-sumber alam juga dapat dikelola sendiri dalam batas-batas yang ditetapkan oleh UU, pembayaran gaji pegawai juga dilakukan oleh daerah sendiri, eksplorasi alam dilakukan sendiri, kepala daerah bertanggung jawab pada DPRD bukan kepada pemerintah pusat.(media Transparansi, edisi 6 Maret 1999)

17 Secara umum data Indonesia Corruption Watch (ICW) dari Januari hingga Desember 2004 mengenai kasus korupsi yang melibatkan anggota Dewan menunjukkan beberapa hal. Pertama, dari sisi jumlah kasus, perbuatan
Karena itu Undang-Undang ini kemudian direvisi dengan hadirnya Undang-Undang Nomor 32 Tahun 2004 Tentang Pokok Pokok Pemerintahan daerah yang dalam beberapa hal mengubah sistem pemerintahan daerah sedemikian rupa sehingga dalam beberapa hal kewenangan mereka menjadi dibatasi kembali. Namun demikian Hadirnya Undang-Undang Nomor 32 Tahun 2004 masih membuka berkembangnya dinamika demokrasi di setiap pemerintahan daerah, khususnya dengan diaturnya sistem pemilihan langsung kepala daerah yang besangkutan, baik di tingkat Propinsi dan Kabupaten. Maksud Undang-Undang tentunya adalah untuk menjamin agar para pemimpin didaerah itu benar-benar yang dikehendaki rakyat setempat. Tetapi dalam praktiknya tidak jarang PILKADA langsung ini justru menimbulkan masalah baru, seperti konflik antar pendukung calon, politik uang, manipulasi suara, gugat menggugat antar calon dan lain-lain yang apabila hal ini terjadi terus menerus dapat menggunggu dan mengancam keutuhan bangsa.

Di Maluku Utara, KPU Pusat telah membatalkan keputusan KPUD, dengan memenangkan pasangan yang kalah menjadi pemenang. Keputusan ini sudah tentu diprotes oleh calon yang telah ditetapkan sebagai pemenang. Sampai sekarang, gubernur baru belum dilantik, dan Pemerintah Pusat bahkan telah mengangkat pejabat gubernur sementara. Kesimpulannya, hasil Pilkada masih terkatung-katung. Menunggu proses hukum. Di Sulawesi Selatan, pasangan yang dinyatakan kalah, mengajukan tuntutan hukum ke Mahkamah Agung (MA) dan MA kemudian memutuskan untuk mengulang Pilkada di beberapa kabupaten. KPUD dan berbagai kalangan memprotes, sementara Wakil Presiden membela keputusan MA. Kesimpulannya, hasil Pilkada Sulawesi terkatung-katung. Pemerintah, mungkin akan terpaksa mengangkat pejabat gubernur, kalau penyelesaian masalah ini tidak terselesaikan dalam waktu singkat, ketika masa jabatan gubernur sekarang habis.

Dua kasus Pilkada itu, disamping kasuskasus yang lain, telah menunjukkan betapa penyelenggaraan Pilkada rawan sengketa. Bagaimana menyelesaikan sengketa pun, ternyata menimbulkan interpretasi hukum yang berbeda.

korupsi yang melibatkan anggota DPRD merupakan jumlah terbanyak, yakni 102 kasus dari total 239 kasus korupsi yang muncul di sebagian besar wilayah di Indonesia.(http://www, antukorupsi.org//mod.php) 
Siapa yang harus menyelesaikan sengketa itu? Di Maluku Utara diselesaikan oleh KPU Pusat, meskipun belum tuntas. Di Sulawesi Selatan oleh MA. Apa yang terjadi, kalau keputusan MA ditolak oleh KPUD? Mengulang Pilkada, berarti akan mengulangi segala proses Pilkada. Mengapa MA tidak memutuskan untuk melakukan penghitungan ulang Pilkada (saja)? Bagaimana pendapat KPU Pusat? KPUD diharapkan dapat melakukan upaya hukum dengan mengajukan PK? Kalau PK nanti menghasilkan keputusan yang berbeda, tidakkah wibawa MA akan tercemar? MA, tanpa disadari, telah bersikap tidak menghargai keputusannya sendiri, meskipun secara hukum sah. Kalau keputusan MA berubah-ubah, bagaimana kita bisa menghargai hukum? Krisis hukum, tampaknya sudah diambang pintu. Bagaimana kita bisa membayangkan kehidupan berbangsa dan bernegara yang tertib, tanpa penegakan hukum yang jelas, pasti, dan berwibawa?

Keterlibatan Wakil Presiden (waktu itu pak Yusuf Kalla), yang berusaha membela keputusan MA, juga menimbulkan permasalahan. Setidaknya menimbulkan kesan politis, oleh karena keputusan MA itu (kebetulan?) memenangkan calon Partai Golkar, partainya Wakil Presiden. Sulit dihindari, adanya kesan, hal itu terkait kepentingan partainya. Seandainyapun tidak dimaksudkan untuk membela calon partainya, kesan seperti itu sulit dihindari. Di masa depan, baik Presiden/Wakil Presiden dan juga para menteri, akan lebih baik, kalau tidak ikut-ikutan mencampuri masalah yang tidak terkait dengan tugasnya sebagai pejabat negara ${ }^{18}$. PILKADA langsung ternyata juga membawa konsekuensi biaya tinggi, yang terkadang melebihi kemampuan daerah, sehingga sering mengganggu keuangan daerah dan pembangunan daerah bersangkutan ${ }^{19}$. Jika hal hal negatif ini kemudian dikaitkan dengan ideologi Pancasila, maka Konflik horizontal, pemilihan langsung

18 Dari PILKADA bermasalah sampai dengan PEMILU 2009. Harian PELITA, 25 Maret 2008.

19 Misalnya untuk PILKADA Jawa Tengah yang berlangsung 22 Juni 2008. anggaran yang harus disediakan sebesar Rp 650 milyar. Padahal APBD Jawa Tengah tahun 2008 hanya sebesar Rp 5 trilyun. Anggaran PILKADA ini berarti menyedot $13 \%$ anggaran belanja Daerah . Dana ini belum termasuk yang dikeluarkan para calon yang akan bertanding dalam PILKADA tersebut . anggaran PIGUB JATENG ini naik menjadi Rp 992 Milyar pada tahun 2018. https://news.detik.com/berita-jawa-tengah. Diunduh 10 Maret 2019. terhadap kepala daerah, korupsi yang belakangan ini marak muncul pasca reformasi tentunya sangat bertentangan dengan nilai-nilai Pancasila. Terutama sila Persatuan Indonesia, Kerakyatan yang dipimpin oleh hikmah Permusyawaratan Perwakilan dan Keadilan Sosial Bagi seluruh rakyat Indonesia. Sehingga wajar bila kemudian muncul gagasan dari kelompok tertentu yang menghendaki perlunya pemurnian Pengamalan Pancasila dengan mengajak kembali ke UndangUndang Dasar $1945^{20}$.

\section{Globalisasi dan Implikasinya terhadap Pengamalan Pancasila}

Globalisasi menurut sejarah, sebenarnya bukan persoalan baru yang muncul di akhir abad sembilan belas, tetapi pembicaraan tentang ekonomi global telah dimulai tahun 1930-an ${ }^{21}$. Pada waktu itu The US Council of Foreign Relation memprakarsai pertemuan antara para pengusaha besar Amerika Serikat dan para penentu kebijakan politik Luar negeri. Forum ini banyak menggagas mengenai kepentingan perusahaan perusahaan besar Amerika Serikat yang ingin menguasai jaringan ekonomi di seluruh belahan dunia. Para anggota forum ini, sejak dini telah menilai bahwa kepentingan nasional Amerika Serikat mensyaratkan perlunya akses perdagangan bebas serta akses terhadap sumber daya alam yang ada di belahan dunia ini. Pada Juli 1941 Forum menyepakati sebuah memorandum mengenai the concept of grand area yang menetapkan sejumlah wilayah dunia yang perlu dikuasai, baik secara ekonomi maupun militer, demi terjamnnya kesediaan bahan baku dunia industri di Amerika

20 Ajakan kembali ke UUD 1945 asli mengemuka tatkala beberapa tokoh seperti Rosihan Anwar, mantan Presiden Abdurrahman Wahid (alm), dan Soetardjo Soerjogoeritno memperingati Dekrit Presiden 5 Juli 1959 di Tugu Proklamasi, Rabu (5/7). Sementara, Tyasno Sudarto hadir di Gedung Perpustakaan Nasional. Sementara itu, dalam kesempatan sama, Gubernur Lemhanas Muladi mengatakan permintaan kembali ke UUD 1945 asli merupakan langkah mundur ke masa lalu. "Pernyataan Pak Tyasno (Jenderal (Pur) Tyasno Sudarto-red) saya kira pernyataan yang aneh. Berarti kita setback, kembali kepada memimpikan pemerintahan yang otoriter. Kalau kita menggunakan UUD 1945 yang murni, hasilnya adalah pemerintahan Orde Baru," kata Muladi. (http://www.rri-online.com/ modules.php)

21 Abdul Kadir Besar, Pancasila dan Era Globalisasi, seminar Peran ABRI abad XXI, AKMIL-TNI AD Magelang, Nopember 1997. hal 17 
Serikat. Forum juga menyerukan disiptakannya industri-industri financial berskala Internasional dalam rangka untuk menstabilkan mata uang dan perwujudan modal.

Dalam sebuah konverensi di Bretton Wood tahun 1944 menteri Keuangan Amerika Serikat Henry Morgenthau menyampaikan seruan mengenai perlunya menciptakan suatu ekonomi dunia yang dinamik, di mana setiap bangsa di dunia dapat merealisasikan potensinya dalam keadaan damai, serta dapat lebih menikmati hasil kemajuan materiil di atas bumi yang dianugerahkan Tuhan berupa kekayaan alam yang tiada batas. Ia mengatakan "kemakmuran itu tidak mempnyai batas, kemakmuran itu bukan substansi yang akan habis oleh pembagian". Akhir pertemuan tersebut kemudian membuahkan berdirinya lembaga keuangan yang disebut World Bank dan International Monetary Fund (IMF) dan disai dasar dari GATT. Institusi ini kemudian bekerja sesuai dengan parannya, yaitu dalam rangka mendongkarak pertumbuhan ekonomi global, sedangkan GATT memperkuat tindakan politik di atas, terutama dalam membuka sistem ekonomi terbuka di negara-negara yang sedang berkembang.

Buah dari kebijakan politik Amerika Serikat ini memang luar biasa, karena di satu sisi memang membawa dampak naiknya pertumbuhan ekonomi dunia dari waktu ke waktu, termasuk di bidang investasi modal asing yang merambah negara-negara berkembang. Namun di balik itu sesungguhnya mereka telah gagal mewujudkan keinginannya, karena jumlah orang miskin ternyata terus meningkat tak terkendalikan ${ }^{22}$.

22 Jumlah penduduk miskin yang tinggal di kotakota besar di seluruh dunia akan lipat dua menjadi dua milyar manusia dalam waktu 30 tahun, kalau tidak diambil langkah-langkah perbaikan dari sekarang. Kata laporan badan PBB, 'Human Settlement Program'; kawasan yang paling banyak terkena saat ini adalah Asia, dimana ada sedikitnya 550 juta orang penghuni kawasan kumuh, dan di Afrika, 190 juta orang. Secara keseluruhan, kata laporan $\mathrm{PBB}$ itu, hampir satu milyar manusia hidup berdesakan di kawasan-kawasan kumuh yang tidak punya fasilitas layanan umum yang paling dasar sekalipun, seperti air minum, listrik dan kebersihan. Kata badan PBB itu, semua negara harus menyadari gawatnya situasi saat ini, dan dimasa depan, kalau masalah kawasan kumuh itu tidak dibereskan. Bahkan di dunia maju juga
Tindakan kekerasan dan penindasan juga terus berlanjut sedangkan kemerosotan ekosistem bumi telah mencapai tingkat yang membahayakan, dan contohnya adalah fenomena pemanasan global. Menurut laporan terakhir Panel PBB tentang Perubahan iklim (United Nations Intergovermental Panel on Climate Change) yang diumumkan di Valencia, Pemanasan global merupakan sesuatu yang tak terbantahkan lagi dan dapat menimbulkan dampak sangat mengerikan. Laporan tersebut menyebut manusia sebagai biang utama pemanasan global. Emisi gas rumah kaca mengalami kenaikan 70 persen antara 1970 hingga 2004. Konsentrasi gas karbondioksida di atmosfer jauh lebih tinggi dari kandungan alaminya dalam 650 ribu tahun terakhir.

Rata-rata temperatur global telah naik 1,3 derajat Fahrenheit (setara 0,72 derat Celcius) dalam 100 tahun terakhir. Muka air laut mengalami kenaikan rata-rata 0,175 centimeter setiap tahun sejak 1961.Sekitar 20 hingga 30 persen spesies tumbuh-tumbuhan dan hewan berisiko punah jika temperatur naik 2,7 derajat Fahrenheit (setara 1,5 derajat Celcius). Jika kenaikan temperatur mencapai 3 derajat Celcius, 40 hingga 70 persen spesies mungkin musnah.

Meski negara-negara miskin yang akan merasakan dampak sangat buruk, perubahan iklim juga melanda negara maju. Pada 2020, 75 juta hingga 250 juta penduduk Afrika akan kekurangan sumber air, penduduk kota-kota besar di Asia akan berisiko terlanda banjir dan rob. Di Eropa, kepuanahan spesies akan ekstensif. sementara di Amerika Utara, gelombang panas makin lama dan menyengat sehingga perebutan sumber air akan semakin tinggi. Kondisi cuaca ekstrim akan menjadi peristiwa rutin. Badai tropis akan lebih sering terjadi dan semakin besar intensitasnya. Gelombang panas dan hujan lebat akan melanda area yang lebih luas. Risiko terjadinya kebakaran hutan dan penyebaran penyakit meningkat.

Sementara itu, kekeringan akan menurunkan produktivitas lahan dan kualitas air. Kenaikan muka air laut akan memicu banjir lebih luas, mengasinkan air tawar, dan menggerus kawasan pesisir $^{23}$.Konflik duniapun terlihat masih terus

terdapat 50 juta penduduk miskin di kawasan kumuh (VAO News Com 7 Oktober 2003)

23 Menurut Kepala Kepala Pusat Data Informasi dan Humas Badan Nasional Penanggulangan Bencana (BNPB), Sutopo Purwo Nugroho, Ada beberapa faktor penyebab anomali cuaca. Di antaranya hangatnya 
bergolak. Hegemoni Amerika Serikat dan sekutunya di berbagai belahan bumi seperti Irak, Afganistan, Kolombia, dan beberapa negara di Afrika semakin menguatkan tesis Forum Bretton Woods di atas. Apa yang dilakukan Amerika Serikat ini -dalam konteks global- tentu berpengaruh pada perkembangan sosial ekonomi dan politik di Indonesia, baik dalam arti yang positif maupun negatif, sebagaimana diramalkan Kenichi Ohmae bahwa arus global cenderung membuat negara negara maju mendominasi kekuatan ekonomi negara berkembang yang kemudian bergantung kehidupanya pada negara maju tersebut ${ }^{24}$

Beberapa hal positif yang lahir sebagai pengaruh globalisasi antara lain pemanfaatan sarana informasi berteknologi tinggi, kebebasan berusaha dan mengemukakan pendapat termasuk kebebasan pers, otonomi daerah dan lain-lainnya. Sementara dampak negatif yang tidak bisa dihindarkan misalnya terjadinya konflik, baik fertikal maupun horizontal ${ }^{25}$. Menurut Siswono

suhu muka laut di atas normal perairan Indonesia barat, masuknya aliran massa udara basah dari samudera India di maritim kontinen Indonesia, lemahnya aliran masa udara dingin Australia di wilayah Indonesia. Lalu adanya daerah perlambatan, pertemuan dan belokan angin di wilayah Sumatera dan Kalimantan, yang mengakibatkan kondisi atmosfer menjadi tidak stabil sehingga terjadi peningkatan curah hujan. (surya. co.id,http://surabaya.tribunnews.com/2016/06/19/ inilah-penyebab-anomali-cuaca-yang-dihadapi-diindonesia. Diunduh 2 Maret 2019.

24 Ohmae Kenichi, The End Of Nation state, The Free Press, p.2

25 Putra Nababan, dalam Suara Pembaharuan, 12 Nopember 2001. Dijelaskan, secara klasik konflik dibagi dua yaitu konflik horizontal dan vertikal. Konflik vertikal ketika terjadi konflik antara penguasa dan masyarakat, sedangkan konflik horizontal itu antara kolompok masyarakat dengan kelompok masyarakat. Pemisahan ini sebenarnya hanya teoritis, dalam prakteknya itu saling terkait. Tidak pernah ada yang murni konflik horizontal atau murni konflik vertikal. Yang patut kita lihat di dalam konflik horizontal adalah bagaimanapun juga tanggung jawab dari negara itu tetap tidak hilang. Bila terjadi konflik horizontal maka sebenarnya yang bertanggung jawab pertama-tama adalah negara, dalam hal ini Pemerintah. Itu hal pertama yang tidak boleh dilupakan. Yang kedua, kalau kita lihat konflik yang ada di Indonesia berdasarkan satu pengamatan yang dalam, satu analisis yang dalam akan sampai kepada dasar dari konflik itu adalah ketidakadilan. Apakah itu di Papua, Aceh, Poso, Maluku, Ambon, dan tempattempat lainnya. Pada bottom line-nya atau dasar dari konflik itu adalah ketidakadilan, ketidakadilan sosial, ketidakadilan ekonomi, ketidakadilan moral, ketidakadilan politik. (Putra Nababan, dalam SUARA PEMBARUAN, 12 Nopmber 2001)
Yudohusodo, Sebenarnya, proses reformasi belakangan ini adalah kesempatan emas yang harus dimanfaatkan secara optimal untuk merevitalisasi semangat dan cita-cita para pendiri negara kita untuk membangun negara Pancasila ini. Sayangnya, peluang untuk melakukan revitalisasi ideologi ini kurang dimanfaatkan. Bahkan dalam proses reformasi-selain sejumlah keberhasilan yang ada, terutama dalam bidang politik-juga muncul ekses berupa melemahnya kesadaran hidup berbangsa. gerakan separatisme, tidak diindahkannya konsensus nasional, pelaksanaan otonomi daerah yang menyuburkan etnosentrisme dan desentralisasi korupsi, demokratisasi yang dimanfaatkan untuk mengembangkan paham sektarian, dan munculnya kelompok-kelompok yang mempromosikan secara terbuka ideologi di luar Pancasila. bahkan menurut Try Sutrisno, saat ini ada kecenderungan terjadinya demokrasi liberal yang ternyata tidak cocok dianut, karena lebih mengutamakan kekeuasaan, dan melahirkan perasaan kedukuan yang berlebihan sehingga setiap kelompok lebih mengutamakan kepentingan dirinya ketimbang kepentingan bangsa dan negara.. Meskipun aksioma Try Sutrisno tidak semuanya benar, tetapi gejala prilaku bangsa ke arah itu semakin terlihat tanda-tandanya, sehingga perlu diwaspadai.

\section{Langkah Hukum untuk Meletakkan Kembali Jiwa Pancasila sebagai Arah Pembangunan Bangsa}

Langkah yang dimaksud dalam tulisan ini bukanlah dalam konteks langkah hukum yang positivistik sebagaimana yang sering ditemukan dalam teks perundang-undangan yang lazim ada di suatu negara (common denominator), karena langkah hukum yang diharapkan dapat menyelesaikan persoalan suatu bangsa tidak mungkin dan tidak cukup hanya dilaksanakan dengan pendekatan hukum yang Formalistik. Banyak peristiwa hukum yang menunjukkan kegagalannya dalam menyelesaikan masalah hukum itu sendiri di negeri ini, misalnya soal kasus BLBI yang oleh kejaksaan Agung akhirnya ditutup karena tidak ditemukan bukti kongkrit adanya penyimpangan. Dalam kasus BLBI ini

25 Siswono Yudohusodo, dalam SUARA PEMBAHARUAN, 23 Mei 2004. Periksa Juga penjelasan Fahri Abdillah tentang dampak positif/ negatif Globalisasi di bidang POLEKSOSBUD, (http:// blok.ruangguru.com, 27 Maret 2018) 
para pengemplang uang negara malah "selamat" sementara justru penegak hukumnya yang ketangkap melanggar hukum karena tuduhan menerima suap. Dalam beberapa kasus, Satjipto Rahardjo memandang bahwa penegakan hukum yang Formal Justice ternyata "gagal" mewujudkan "potret" hukum yang benar, sebagai akibat penegak hukum yang hanya mengabdi pada hukum perundang-undangan semata ${ }^{26}$. Bertitik tolak dari pandangan di atas,sangatlah tidak cukup bila upaya untuk menggali kembali nilai Pancasila hanya dilakukan dengan mencoba memunculkan ide "kembali ke UUD 1945" dalam arti kemudian mencabut amandemen UUD 1945 sebagaimana peristiwa dekrit Presiden 5 Juli $1959^{27}$.

Orang sebenarnya tahu bahwa bahwa Pancasila adalah ideologi negara dan bangsa, karena pengakuan ini masih utuh dan konstitusional hingga kini, meskipun ada sejarah amandemen pasca reformasi ${ }^{28}$. Pancasila hinggga kini juga tetap dikumandangkan dalam berbagai upacara resmi tanpa dikurangi sedikitpun urutan maupun isi kalimatnya. Hal ini dilakukan dengan maksud agarkehidupan sehari hari kita selalu berpegang teguh pada nilai-nilai dalam setiap sila dari Pancasila itu. Tetapi di dalam praktik pelaksanaanya ternyata tetap terjadi praktik-praktik yang melanggar nilai nila Pancasila sebagaimana secara kasat mata bisa dilihat. Misalnya praktik KKN yang masih terus berlangsung, saling hujat antar kelompok, terlebih di saat jelang pelaksanaan pesta demokrasi sebagaimana berlangsung saat ini. Tampaknya ada yang salah di dalam mengamalkan Pancasila ini, dan kesalahan itu seyogyanya harus segera diantisipasi. Menurut Nonet dan Selznick kegagalan menyelesaikan persoalan di masyarakat adalah karena justru karena hanya melihat hukum dalam konteks ke dalam saja (positivism) dan tidak ke luar $^{29}$. Alasan yang sama juga disampaikan Karl Renner dengan preposisinya "the development of the law gradually works out what is socially reasonable" ${ }^{\prime 30}$.

26 Satjipto Rahardjo, Hukum Dalam Jagad Ketertiban, UKI Press,2006, hal 29-30

27 Try Sutrisno, Loc-cit

28 MPR sepakat bahwa Pembukaan UUD 1945 dipertahankan untuk tidak diubah. Dengan demikian secara yuridis konstitusional mengandung makna bahwa Pancasila sebagai edeologi bangsa tetap kokoh dan diakui.

29 Dalam Satjipto Rahardjo, op-cit, Hal 31

30 Karl Renner, dalam Satjipto Rahardjo, loc-cit
Intinya, bahwa tidak semua persoalan bisa. diselesaikan dengan hukum, tetapi butuk bantuan dari "ilmu" lain di luar hukum. Pendekatan multidisipliner menjadi alternativ yang harus dilakukan dalam menyelesaikan persoalan bangsa ini. Inilah yang kemudian oleh Satjipto Rahardjo dinisbatkan sebagai metoda Holistik, sebagai bagian dari cara menemukan penyelesaian hukum yang tidak hanya Adil, tetapi juga benar (the truth of law). salah satu pendekatan holistik, misalnya dengan melakukan sinergi dengan ilmu psikologi yang dikemas dalam konsep Humane psichology yang dalam perkembangannya memunculkan tiga teori tentang Spiritual Quotien (SQ), Intelectual Quotien (IQ) dan Emotional Quotien (EQ) ${ }^{31}$. Jika hal ini dikaitkan dengan tesis Auguste Comte, maka yang disampaikan Satjipto Rahardjo ini sesungguhnya merupakan upaya untuk mencoba berfikir tentang hukum secara mendalam, yang tidak sekedar positivis analitis, tetapi juga tetap mengedepankan aspek metafisis dan teologis (holistik).

Pendekatan Holistic ini sesungguhnya pernah diketengahkan juga oleh Edward $\mathrm{O}$ Wilson, dengan istilah Etics an Religion sebagai salah satu cara menyelesaikan problem sosial. Dia menegaskan bahwa "that the Religion has an overwhelmingattraction for the human mind, and the religious conviction is largely beneficient. Religion riss from the innermost coil of human spirit. It nourishes love, devation and above all hope. People hunger for the assurance it offer" ${ }^{\prime 2}$. Pengamalan Pancasila secara baik dan benarsesungguhnya merupakan bagian dari paradigma ini, sebab jika seluruh sila dari Pancasila itu dilaksanakan secara sungguh-sungguh maka di sana banyak norma agama yang membimbing manusia ke jalan yang benar.manusia harus berbuat baik terhadap sesama seperti dalil Al Qur'an, surat AL Qashas ayat (27).

John Naisbit dan Patricia Aburdene pernah mengatakan "Schene and Technology do not tell us whats life means" tetapi "both religion and science is to find truth" karena itu "we learn that throughliterature, the art and spiritually" 33. Dikabarkan bahwa trend pendekatan spiritual ini bahkan kini masuk dalam kalangan bisnis

31 Zohar dan Marshall, dalam Satjipto Rahardjo, Loc-cit

32 Edward O Wilson, Concilience, the Unity of Knowledge, Alfred a Knoff, New York, 1988, p.243

33 John Naibitt \& PatriciaAburdene, Mega Trend 2000, Avon Book, New York, 1990. P292-293 
seperti yang terjadi di Pacivic Bell California yang mewajibkan 67.000 karyawanya mengikuti pelatihan spiritual ala new $\mathrm{Age}^{34}$.

Menurut Ary Ginanjar, di dalam diri manusia ada tiga potensi yang berdimensi spiritual, emosional dan fisik. Pada dimensi spiritual dikenal adanya energi Ilahiah yang merupakan kekuatan inti dari manusia, dan ini terletak pada orbit yang dinamakan God Spot. Pada dimensi emosional, manusia mengenal dan memiliki radar hati yang berfungsi menangkap sinyal - sinyal, apakah kreatifitas fisik kita masih diluar garis atau sudah masuk manzilah. Dengan radar emosi inilah manusia bisa memantau aktivitas fisik dan ruhiyah dari dalam kemudian keluar. Pada dimensi luar atau fisik, idealisme spiritual akan diubah ke dalam bentuk nyata. Suara ahti tidak hanya disimpan tetapi harus diubah atau diaplikasikan di dalam tindakan nyata. Contoh, kasih sayang bukan hanya hati, namun diaplikasikan dnegan langkah riil. Sifat kreatif diaplikasikan. Kejujuran ditunjukan. Berhati jernih dirasakan dan dipergunakan dalam memulai aktivitas. Cintsa damai dilaksanakan, pemaaf dijalankan. Disiplin diaplikasikan dan diterapkan dalam keseharian. Pada saat itulah dimensi fisik dengan kecerdasan spritual perlu bersinergi untuk menghasilkan kekuatan baru dalam menguraikan berbagai persoalan bangsa yang multi dimensional itu, khususnya di saat tantangan persoalan bangsa semakin kompleks.

\section{Simpulan}

1. Gerakan Reformasi di Indonesia yang terjadi di akhir abad 19, secara yuridis normatif memang berpengaruh pada bergesernya pemahaman dan pengamalan nilai Pancasila di negeri Indonesia tercinta ini, karena aspek bordeless peradaban dari luar yang sulit dibendung.

2. Globalisasi suka atau tidak suka ternyata memang mebawa dampak pergeseran dan perubahan paradigma kehidupan manusia, baik dalam berbangsa dan bernegara. Eksistensi Pancasila sebagai dasar dan ideologi negara secara langsung dan tidak langsung juga terkena imbasnya.

3. Upaya untuk meletakan kembali jiwa pancasila sebagai arah pembangunan bangsa

34 Begitu pula Perusahaan raksasa lain seperti Proter \&Gamblee, Ford Company,AT\&T, IBM, General Motor dll (periksa Ari Ginanjar Agustian, dalam ESQ Power, 2003. Hal 8) tidak perlu merubah tatanan hukum yang ada, tetapi dilakukan dengan cara pendekatan sosial. Bahkan lebih luas dari itu (holistik). Peran agama/spiritual menjadi pilihan yang tepat untuk mengatasi problem sosial yang terjadi.

\section{Daftar Pustaka}

Abdul Kadir Besar, Pancasila dan Era Globalisasi, AKMIL Magelang, 1997

Anonim, Bahan Penataran P4, BP7 Pusat, Jakarta, 1990

Anonim, Panduan Pemasyarakatan UndangUndang Dasar Republik Indonesia Tahun 1945, Sekretaris Jendral Majelis Permusyawaratan Rakyat Republik Indonesia, 2005.

Anonim, Ringkasan Eksekutif, implikasi reposisi TNI-POLRI di Bidang hukum, non tahun, non Kota.

Ginanjar Ari, Agustian, Rahasia Sukses Membangkitkan ESQ Power, Arga Jakarta, 2003

Jerry Mender \& Edward Coldsmith, The Case Again Global Economy and For Return Toward The Local, seira club books, san fransisco. 1996.

Kinichi Oh Mae, The end of Nation State, The Free Press, New York, 1995

Nais Bitt John \& Patricia Abordene, Mega tren 2000, afon books, New York. 1998

Raharjo, Satjipto, Hukum Dalam Jagad Ketertiban, UKI Press, Jakarta 2006.

Roland Robertson, Globalization, SAGE Publication, LTD, London, 1993

Wibisono, Kunto, Siswomiharjo, Pancasila dan Era Globalisasi, Seminar AKMIL, Magelang, 1997

Wilson O Edward, Concilience, The Unity Of Knoeledge, alfretknof, New York, 1998. 